\title{
ASSESSMENT OF TECHNOLOGY COMPETITIVENESS ABILITIES IN INDONESIAN WAR SHIP IN ASIA
}

\author{
Harun Bekti Ariyoko, I Nengah Putra, Okol Sri Suharyo \\ Indonesian Naval Technology College, \\ Bumimoro-Morokrembangan, Surabaya 60187, Indonesia
}

\begin{abstract}
The assessment of technological competitiveness can be carried out at the level of a stage of transformation on a warship. With the dynamics of defence and security threats to the Indonesian state, both symmetrical and asymmetrical, warship technology must continue to improve combat capability and professionalism of human resources in accordance with technological developments towards the industrial revolution 4.0, in order to have a high level of competitiveness. The purpose of this study is to determine the strengths and weaknesses of warship performance through the assessment of technological capabilities. The research result, at the level of technological capability and the existing gap of fourth components, where the current level of capability on warships $W$ has a gap of the technological development that is farthest away with countries $Y$ and $Z$ is the development of the level of technological capability on technical devices and followed by developments the level of technological capability in human resources (soldiers). The benefits of the research are expected to be used as material for consideration by planners and decision makers in integrating technological considerations into the planning of warship development in the modern era.
\end{abstract}

Keywords: Technology Capability Assessment, Warship Technology, Techometrics

\section{INTRODUCTION}

The progress of the military industry is usually marked by the extent of the capability and independence of its military technology. Technology capability in general can be interpreted as the ability of the warship industry to develop its own technology and to assimilate from various types of imported technology (Alkadri, Dodi, Muchdie, Siswanto, \& Fathoni, 2001). Technology independence is the ability of the warship industry to implement and determine various programs, policies and operational industries, so that the dependence of technology on other parties can be reduced or minimized (Alkadri, Dodi, Muchdie, Siswanto, \& Fathoni, 2001). In the era of the industrial revolution 4.0, the rapid pace of innovation and the rapid introduction of new technology, which means that the prediction of technology will change naval operations has always been a challenge in the modern era (Sadler, 2015). New technology impacts changes in the defence system and various fields of military and takes place quickly and continuously, and provides new and more effective military capabilities (James, 2013), and there have occure many changes in information and other function of technology (Putra, Hakim, Pramono, \& Tolle, 2017). This shows that the availability of technology as a tool in realizing and multiplying the potential of operational capabilities of warships is increasingly widespread and becomes dominant in increasing combat capability and will have a transformational effect on naval operations (Kenny \& et.al, 2015). New technological developments have the potential to change the environment in which the military operates and can change the balance of power, create new forms of insecurity, change censorship systems, weapons systems, command and control systems, organizations and information very quickly and change military doctrine and change the pattern of future warfare patterns becomes very dynamic (James, 2013) (Kenny \& et.al, 2015). For this reason, technological transformation needs to be measured explicitly (Ramadhani, 2012), so that warships know their current capability position, then plan for improvements and enhancements that are felt technology through meeting technological needs. Hope in the future can anticipate all threats both symmetrical, asymmetrical to hybrid threats.

PKR SIGMA 10514 type, KRI Raden Eddy Martadinata-331 (REM-331) was the first ship built at the domestic PT shipyard PT PAL Indonesia, in cooperation with the Dutch ship company Damen Schiede Naval Ship Building (DSNS), which became the fifth vessel applying SIGMA technology, and designed to carry out various missions, namely antiship warfare on water, anti-air attack warfare, antisubmarine warfare, and electronic warfare. Therefore, evaluation of technological competitiveness on PKR SIGMA 10514 ships is needed both in terms of internal and external. Therefore, the need for research and study on the extent of deficiencies related to military technology in the future can improve the quality and the professionalism of the crew, and has a level of competitiveness of warship technology in high combat capability in the Asian region. The research questions in this paper are: 
a. Based on the level of technological capability, where is the level of technological competitiveness of PKR SIGMA 10514 warships?

b. What is the suggested solution to minimize the technology warship gap?

The approach used in knowing the capabilities of the battleship technology competitiveness at this time is to use the application of technology management so that the value of technology in the warship can be measured by using the technological method approach. The benefits of this research can be used as a consideration for the leadership and at the same time the user can be used as material for consideration by planners and decision makers in integrating technological considerations into planning the construction of warships in the modern era by increasing combat capability. To measure the ability of technological competitiveness with the ability to combat in the face of threats, it is necessary to benchmark with ships of the same class type owned by countries $X$ and $Y$ in the ASEAN region. Assuming, the use of the budget does not count.

Some of the literature that supports this research include, Research by Mahdi et al (2014) about Developing a Model for Technological Capability Assessment (Case of Automotive Parts Manufacturers in Iran). Research by Wei Jiang (2001) about Technological capability assessment as a strategic tool: cases in Chinese manufacturing firms. Research by Abbas khamseh et.al (2014) about Assessment and Analysis of Technological Capabilities in Iranian Oil \& Gas Industries (Case study: Oil and Energy Industries Development Company of Qeshm). Research by João Correia (2019) about Military Capabilities and The Strategic Planning Conundrum. Research by Ciptomulyono and Handayani (2003) concerning the Implementation of the ANP Approach in the Techometric Method for Technology Content Analysis (Case Study: PT. Platinum Ceramics Industri) in Surabaya. Research by Kusumaningtyas (2010) concerning the Implementation of Technology Assessment in Air Traffic Control at Juanda Airport Using Technometric Approach. And research from Yuliastuti Ramadhani (Ramadhani, 2012) about the Company's Competitiveness Analysis in terms of Technology Assessment. Other research by Phaal et.al (2001), technology capability of an organization is similar to technology management capabilities in selection, acquisition, utilization, development and discussion of technologies, and Phaal et.al (2004) about A framework for supporting the management of technological knowledge.

\section{MATERIAL AND METHODS}

The research method applied is through secondary data surveys through the collection and processing of data from several publications that present information and data on the development of warships, and primary data surveys by distributing questionnaires to expert judgment. Expert judgment in this study came from several practitioners and professionals in warships, who was directly involved in every operational and training activity by utilizing aspects of military technology.

\subsection{The Technometric Method.}

The Technometric Method is the Technology Atlas Project Method approach of the Economic and Commission for Asia and the Pacific (ESCAP) in Jerusalem (2002) includes four components, namely:

a. Technoware (T), i.e. Object embodied technology = physical facilities = technical devices. Includes equipment, equipment, machinery, physical infrastructure that is used by humans.

b. Humanware $(\mathrm{H})$, i.e. Person embodied technology = human abilities = human resource capabilities. Includes knowledge, creativity, skills, wisdom, and experience in using natural resources and available technological resources.

c. Infoware (I), i.e. Document embodied technology = document fact = information device: related to procedures, processes, methods, techniques, theories, designs, specifications, observations, manuals obtained through documentation, publications, and others.

d. Orgaware $(\mathrm{O})$, namely Institution-embodied technology = organizational framework = organizational / institutional devices. To accommodate human capabilities, physical facilities, and facts through organizational management in achieving effective and efficient results.

The Technological Approach aims to measure the combined contribution of the four technology components in a process of transforming inputs into outputs. This combined contribution can also be referred to as a technological contribution. The research method is used to assess the ability of technology.

\subsection{Concept of Technology Capability Assessment}

The development of contemporary technology and the need to use modern technology shows the increasing need for technological assessment. Technology assessment is a framework or intellectual instrument that contributes to better assessing technological capabilities, so the development and application of new technologies must be accompanied by an assessment of the current technological conditions (MIRVAKILİ, 2015). Technology capability assessment can be defined as a technology audit to determine and assess gaps (current level of technology and ideal technology), as well as highlighting the factors that influence technology gaps and evaluating the ability of technology to formulate problems faced (Brown, 2004).

The assessment of technological capabilities is basically a combination of the ability to assimilate imported technology, then can develop their own 
technology (local). Where the ability is influenced by how much the availability of technological infrastructure, natural resources, and human resources (ESCAP, 1988e). The study of technological capabilities with the techometrics method in this study was analysed based on the stages of the development of technological components traversed by warships. In ASIA countries, the technological capabilities of warships are relatively the same because some of the technological components are also developing simultaneously. Thus, in the development of technological capabilities of warships can be assessed through the stages of the development of four technological components, including the development of technical devices, human resources, information devices, and organizational tools (Technology Atlas Project Team, 1987) (Sharif, 1988).

Table 1. Stages of the development of technological components

\begin{tabular}{|l|l|l|l|l|l|l|l|}
\hline \multirow{2}{*}{ Stages } & \multicolumn{2}{|c|}{ Technical devices } & \multicolumn{2}{c|}{ Human Resources (soldier) } & \multicolumn{2}{c|}{ Information devices } & Organization \\
& \multicolumn{1}{|c|}{ Local } & \multicolumn{1}{c|}{ Import } & \multicolumn{1}{c|}{ Domestic } & International & \multicolumn{1}{|c|}{ Local } & \multicolumn{1}{c|}{ Import } & devices \\
\hline I & Researching & Selecting & Rearing & & Generating & Obtaining & Conceiving \\
\hline II & Developing & Adapting & Telling & & Screening & Preparing \\
\hline III & Testing & & Teaching & Teaching & Classifying & Designing \\
\hline IV & Demonstrating & & Educating & Educating & Associating & Installing \\
\hline V & Producing & & Training & Training & Analysing & Operating \\
\hline VI & Diffusing & & Strengthening & Strengthening & Synthesizing & Guiding \\
\hline VII & Substituting & & Upgrading & Upgrading & Emulating & Envolving \\
\hline
\end{tabular}

Source: (ESCAP, 1988e) and (Sharif, 1988)

The strength of each stage of development of the technology component is basically determined by three supporting parameters, namely the number of members, labour, and facilities provided. In assessing the three parameters required the right criteria so that the strength of each stage of the development of technological components can be compared at once can be measured. Determination of the measured criteria at the technology development stage is presented according to the following table:

Table 2. The ability criteria for the strength of the developmental stages of the technical device.

\begin{tabular}{|c|c|c|}
\hline Stages & Assessment criteria & Score \\
\hline $\begin{array}{l}\text { Researching and } \\
\text { selecting }\end{array}$ & $\begin{array}{l}\text { Number of R\&D personnel } \\
\text { Number of } R \& D \text { laboratories } \\
\text { Diverse uses of technology }\end{array}$ & $\begin{array}{l}100 \%=10,0 \%=0 \\
10=10,0=0 \\
10=10,0=0\end{array}$ \\
\hline $\begin{array}{l}\text { Developing and } \\
\text { adapting }\end{array}$ & $\begin{array}{l}\text { Experts involved } \\
\text { Computerized and integrated facilities available } \\
\text { The degree of ergonomic application in the equipment }\end{array}$ & $\begin{array}{l}50 \%=10,0 \%=0 \\
\text { Use high }=10, \text { low }=0 \\
\text { Good }=10, \text { bad }=0\end{array}$ \\
\hline Testing & $\begin{array}{l}\text { Number of testing laboratories } \\
\text { The level of sophistication of the testing facility } \\
\text { Reliability of equipments }\end{array}$ & $\begin{array}{l}100=10,0=0 \\
\text { Advanced }=10, \text { conventional }=0 \\
\text { Reliable }=10, \text { No }=0\end{array}$ \\
\hline Demonstrating & $\begin{array}{l}\text { Proportion of personnel involved } \\
\text { The scale of the pilot project facility } \\
\text { Adequacy of control equipment }\end{array}$ & $\begin{array}{l}\text { High }=10, \text { low }=0 \\
10=10,0=0 \\
\text { Complete }=10, \text { less }=0\end{array}$ \\
\hline Producing & $\begin{array}{l}\text { Proportion of personnel involved } \\
\text { Types of institutions / agencies involved } \\
\text { Diverse uses of technology }\end{array}$ & $\begin{array}{l}\text { Big }=10, \text { small }=0 \\
\text { Industry }=10, R \& D=5, \text { none }=0 \\
\text { Large }=10, \text { low }=0\end{array}$ \\
\hline Diffusing & $\begin{array}{l}\text { Proportion of personnel } \\
\text { Number of facilities }\end{array}$ & $\begin{array}{l}\text { High }=10, \text { low }=0 \\
\text { High }=10, \text { low }=0\end{array}$ \\
\hline $\begin{array}{l}\text { Substituting / quality } \\
\text { development }\end{array}$ & $\begin{array}{l}\text { Proportion of personnel involved } \\
\text { Scope of quality improvement and development } \\
\text { The level of technological novelty (the technological situation } \\
\text { in its life cycle) }\end{array}$ & $\begin{array}{l}\text { High }=10, \text { low }=0 \\
\text { Comprehensive }=10, \text { random }=0 \\
\text { Updated }=10, \text { not updated }=0\end{array}$ \\
\hline
\end{tabular}

Source: (ESCAP, 1988e) page 75, processed by researchers

Table 3. Criteria for evaluating the ability of developmental stages of human resources (soldiers)

\begin{tabular}{|l|l|l|}
\hline \multicolumn{1}{|c|}{ Stages } & \multicolumn{1}{|c|}{ Assessment criteria } & \multicolumn{1}{c|}{ Score } \\
\hline Rearing & $\begin{array}{l}\text { Proportion of personnel involved } \\
\text { Availability of educational facilities }\end{array}$ & $\begin{array}{l}\text { High }=10, \text { low }=0 \\
\text { Widely distributed }=10, \text { limited }=0\end{array}$ \\
\hline Basic education & $\begin{array}{l}\text { Proportion of personnel involved } \\
\text { Percentage of availability of facilities and materials in } \\
\text { educating }\end{array}$ & $\begin{array}{l}\text { High }=10, \text { low }=0 \\
100 \%=10,0 \%=0\end{array}$ \\
\hline Teaching & $\begin{array}{l}\text { Proportion of personnel involved } \\
\text { Percentage of coverage of teacher development }\end{array}$ & $\begin{array}{l}\text { High }=10, \text { low }=0 \\
100 \%=10,0 \%=0\end{array}$ \\
\hline
\end{tabular}




\begin{tabular}{|l|l|l|}
\hline \multicolumn{1}{|c|}{ Stages } & \multicolumn{1}{|c|}{ Assessment criteria } & \multicolumn{1}{c|}{ Score } \\
\hline Educating & $\begin{array}{l}\text { The ratio of educators to students } \\
\text { Percentage of coverage / frequency of education }\end{array}$ & $\begin{array}{l}\text { High }=10, \text { low }=0 \\
100 \%=10,0 \%=0\end{array}$ \\
\hline Training & $\begin{array}{l}\text { Ratio of trainers to students trained } \\
\text { Percentage of population coverage by educational institutions }\end{array}$ & $\begin{array}{l}\text { High }=10, \text { low }=0 \\
100 \%=10,0 \%=0\end{array}$ \\
\hline $\begin{array}{l}\text { Strengthening/ } \\
\text { deepening }\end{array}$ & $\begin{array}{l}\text { Proportion of personnel involved } \\
\text { Scope / frequency of training and HR development institutions }=10, \text { low }=0 \\
\text { High }=10, \text { low }=0\end{array}$ \\
$\begin{array}{l}\text { Upgrading and } \\
\text { Developing }\end{array}$ & $\begin{array}{l}\text { Proportion of personnel involved } \\
\text { Regular implementation of education and training programs }\end{array}$ & $\begin{array}{l}\text { High }=10, \text { low }=0 \\
\text { High }=10, \text { low }=0\end{array}$ \\
\hline
\end{tabular}
Source: (ESCAP, 1988e) page 75, processed by researchers

Table 4. Criteria for assessing the ability of the developmental stages of the information devices

\begin{tabular}{|c|c|c|}
\hline Stages & Assessment criteria & Score \\
\hline $\begin{array}{l}\text { Generating and } \\
\text { obtaining }\end{array}$ & $\begin{array}{l}\text { Proportion of personnel involved } \\
\text { Status of documentation center: } \\
\text { - Number and type } \\
\text { - Information service level } \\
\text { - Coverage / duration (minutes) of accumulated information } \\
\text { and data }\end{array}$ & $\begin{array}{l}\text { High }=10, \text { low }=0 \\
\text { High }=10, \text { low }=0\end{array}$ \\
\hline Screening & $\begin{array}{l}\text { Proportion of personnel involved } \\
\text { Screening Mechanism } \\
\text { The level of discipline in the screening process } \\
\text { The level of development of screening methods }\end{array}$ & $\begin{array}{l}\text { High }=10, \text { low }=0 \\
\text { High }=10, \text { low }=0 \\
\text { High }=10, \text { low }=0 \\
\text { High }=10, \text { low }=0\end{array}$ \\
\hline Classifying & $\begin{array}{l}\text { Proportion of personnel involved } \\
\text { Use of facilities: } \\
\text { - classification scheme } \\
\text { - Use of software } \\
\text { - Integrity of the classification scheme }\end{array}$ & $\begin{array}{l}\text { High }=10, \text { low }=0 \\
\text { High }=10, \text { low }=0\end{array}$ \\
\hline Associating & $\begin{array}{l}\text { Proportion [personnel involved } \\
\text { Use of facilities: } \\
\text { - Coverage of the association } \\
\text { - Network database available } \\
\text { - Forecasting technology used }\end{array}$ & $\begin{array}{l}\text { High }=10, \text { low }=0 \\
\text { High }=10, \text { low }=0\end{array}$ \\
\hline Analysing & $\begin{array}{l}\text { Proportion of personnel involved } \\
\text { Amenities: } \\
\text { - monitoring system } \\
\text { - Identification system } \\
\text { - Tracking system }\end{array}$ & $\begin{array}{l}\text { High }=10, \text { low }=0 \\
\text { High }=10, \text { low }=0\end{array}$ \\
\hline Synthesizing & $\begin{array}{l}\text { Proportion of personnel involved } \\
\text { Many facilities / wide distribution }\end{array}$ & $\begin{array}{l}\text { High }=10, \text { low }=0 \\
\text { High }=10, \text { low }=0\end{array}$ \\
\hline Emulating & $\begin{array}{l}\text { Proportion of personnel involved } \\
\text { Use of a computerized SEWACO system }\end{array}$ & $\begin{array}{l}\text { High }=10, \text { low }=0 \\
\text { High }=10, \text { low }=0\end{array}$ \\
\hline
\end{tabular}

Source: (ESCAP, 1988e) page 75, processed by researchers

Table 5. The ability criteria for the strength of the developmental stages of the organizational devices

\begin{tabular}{|l|l|l|}
\hline \multicolumn{1}{|c|}{ Stages } & \multicolumn{1}{|c|}{ Assessment criteria } & \multicolumn{1}{c|}{ Score } \\
\hline Conceiving & $\begin{array}{l}\text { Proportion of personnel involved } \\
\text { Number of divisions and departments that are owned }\end{array}$ & $\begin{array}{l}\text { High }=10, \text { low }=0 \\
100 \%=10,0 \%=0\end{array}$ \\
\hline Preparing & $\begin{array}{l}\text { Proportion of personnel involved } \\
\text { Operational planning made }\end{array}$ & $\begin{array}{l}\text { High }=10, \text { low }=0 \\
100 \%=10,0 \%=0\end{array}$ \\
\hline Designing & $\begin{array}{l}\text { Proportion of personnel involved } \\
\text { Facility to design a combat organization }\end{array}$ & $\begin{array}{l}\text { High }=10, \text { low }=0 \\
\text { High }=10, \text { low }=0\end{array}$ \\
\hline Installing & $\begin{array}{l}\text { Proportion of personnel involved } \\
\text { Facility for diversification of departmental forms in response } \\
\text { to field dynamics }\end{array}$ & $\begin{array}{l}\text { High }=10, \text { low }=0 \\
\text { High }=10, \text { low }=0\end{array}$ \\
\hline Operating & $\begin{array}{l}\text { Proportion of personnel involved } \\
\text { The number and type of departments that are } \\
\text { accommodated and involved }\end{array}$ & $\begin{array}{l}\text { High }=10, \text { low }=0 \\
\text { High }=10, \text { low }=0\end{array}$ \\
\hline Guiding & $\begin{array}{l}\text { Proportion of personnel involved } \\
\text { Number of facilities for strategic planning }\end{array}$ & $\begin{array}{l}\text { High }=10, \text { low }=0 \\
100 \%=10,0 \%=0\end{array}$ \\
\hline
\end{tabular}




\begin{tabular}{|l|l|l|}
\hline Envolving & $\begin{array}{l}\text { Proportion of personnel involved } \\
\text { Number of facilities for coordination mechanisms, } \\
\text { adaptability of the strategic environment, and battle study } \\
\text { analysis }\end{array}$ & $\begin{array}{l}\text { High }=10, \text { low }=0 \\
\text { High }=10, \text { low }=0\end{array}$ \\
\hline
\end{tabular}

Source: (ESCAP, 1988e) page 75, processed by researchers

\section{RESULTS AND DISCUSSION}

In applying the technology capability assessment to 3 warships from Indonesia $(X), Y$ countries and $Z$ countries, with the same type, a different metric level was obtained from the warship's technological capabilities. Based on the sum of the scores, the answers to each of the assessment criteria from the ability assessment stage using a questionnaire and collecting data from warships in each country $\mathrm{X}, \mathrm{Y}$ and $\mathrm{Z}$, and conducting interviews with experts. A compilation of capability assessments is shown in the following table:

Table 6. The level of technological capability in each stage and the level of the gap in technical devices

\begin{tabular}{|l|c|c|c|c|}
\hline \multirow{2}{*}{ Stages } & $\begin{array}{c}\text { Existing } \\
\text { Capability }\end{array}$ & $\begin{array}{c}\text { Existing } \\
\text { Capability }\end{array}$ & $\begin{array}{c}\text { Existing } \\
\text { Capability }\end{array}$ & \multirow{2}{*}{$\begin{array}{c}\text { Ideal } \\
\text { Level }\end{array}$} \\
\cline { 2 - 4 } & $\mathbf{W}$ & $\mathbf{Y}$ & $\mathbf{Z}$ & \\
\hline Researching and selecting & 0,780 & 0,900 & 0,930 & 1,000 \\
\hline Developing and adapting & 0,700 & 0,910 & 0,940 & 1,000 \\
\hline Testing & 0,710 & 0,920 & 0,920 & 1,000 \\
\hline Demonstrating & 0,750 & 0,920 & 0,930 & 1,000 \\
\hline Producing & 0,630 & 1,000 & 1,000 & 1,000 \\
\hline Diffusing & 0,680 & 1,000 & 1,000 & 1,000 \\
\hline Substituting / quality development & 0,710 & 0,980 & 1,000 & 1,000 \\
\hline
\end{tabular}

Table 7. The level of technological ability in each stage and the level of the gap in human resources (soldiers).

\begin{tabular}{|l|c|c|c|c|}
\hline \multirow{2}{*}{ Stages } & $\begin{array}{c}\text { Existing } \\
\text { Capability }\end{array}$ & $\begin{array}{c}\text { Existing } \\
\text { Capability }\end{array}$ & $\begin{array}{c}\text { Existing } \\
\text { Capability }\end{array}$ & \multirow{2}{*}{$\begin{array}{c}\text { Ideal } \\
\text { level }\end{array}$} \\
\cline { 2 - 4 } & $\mathbf{W}$ & $\mathbf{Y}$ & $\mathbf{Z}$ & \\
\hline Rearing & 0,690 & 0,980 & 0,980 & 1,000 \\
\hline Pendidikan dasar & 0,720 & 0,970 & 0,970 & 1,000 \\
\hline Teaching & 0,750 & 0,960 & 0,960 & 1,000 \\
\hline Educating & 0,780 & 0,960 & 0,960 & 1,000 \\
\hline Training & 0,820 & 0,980 & 0,980 & 1,000 \\
\hline Strengthening/pendalaman & 0,790 & 1,000 & 1,000 & 1,000 \\
\hline Upgrading and Developing & 0,800 & 1,000 & 1,000 & 1,000 \\
\hline Mean & 0,764 & 0,979 & 0,979 &
\end{tabular}

Table 8. The level of technological capability in each stage and the level of the gap in information devices.

\begin{tabular}{|l|c|c|c|c|}
\hline \multirow{2}{*}{ Stages } & $\begin{array}{c}\text { Existing } \\
\text { Capability }\end{array}$ & $\begin{array}{c}\text { Existing } \\
\text { Capability }\end{array}$ & $\begin{array}{c}\text { Existing } \\
\text { Capability }\end{array}$ & \multirow{2}{*}{$\begin{array}{c}\text { Ideal } \\
\text { level }\end{array}$} \\
\cline { 2 - 4 } & $\mathbf{W}$ & $\mathbf{Y}$ & $\mathbf{Z}$ & \\
\hline Generating and obtaining & 0,920 & 0,980 & 0,980 & 1,000 \\
\hline Screening & 0,900 & 0,970 & 0,970 & 1,000 \\
\hline Classifying & 0,950 & 0,960 & 0,960 & 1,000 \\
\hline Associating & 0,960 & 0,960 & 0,960 & 1,000 \\
\hline Analysing & 0,940 & 0,980 & 0,980 & 1,000 \\
\hline Synthesizing & 0,900 & 0,890 & 0,900 & 1,000 \\
\hline Emulating & 0,890 & 0,890 & 0,900 & 1,000 \\
\hline Mean & 0,923 & 0,947 & 0,950 &
\end{tabular}

Table 9. The level of technological capability in each stage and the level of the gap in the organizational device. 


\begin{tabular}{|l|c|c|c|c|}
\hline \multirow{2}{*}{ Stages } & $\begin{array}{c}\text { Existing } \\
\text { Capability }\end{array}$ & $\begin{array}{c}\text { Existing } \\
\text { Capability }\end{array}$ & $\begin{array}{c}\text { Existing } \\
\text { Capability }\end{array}$ & \multirow{2}{*}{$\begin{array}{c}\text { Ideal } \\
\text { level }\end{array}$} \\
\cline { 2 - 4 } & $\mathbf{W}$ & $\mathbf{Y}$ & $\mathbf{Z}$ & \\
\hline Conceiving & 0,690 & 0,880 & 0,890 & 1,000 \\
\hline Preparing & 0,720 & 0,890 & 0,880 & 1,000 \\
\hline Designing & 0,750 & 0,920 & 0,930 & 1,000 \\
\hline Installing & 0,800 & 0,900 & 0,920 & 1,000 \\
\hline Operating & 0,820 & 0,920 & 0,940 & 1,000 \\
\hline Guiding & 0,850 & 0,900 & 0,900 & 1,000 \\
\hline Envolving & 0,800 & 0,890 & 0,890 & 1,000 \\
\hline Mean & 0,776 & 0,900 & 0,907 &
\end{tabular}

From the table above it can be collected, the level of technological capability based on the four stages in its development in the technical rankings, human resources (soldiers), information devices, and organizational tools, in the following table:

Table 10. An assessment of the ability of the developmental stages of the four components

\begin{tabular}{|l|c|c|c|c|}
\hline \multicolumn{1}{|c|}{ Stages } & $\begin{array}{c}\text { Existing } \\
\text { Capability W }\end{array}$ & $\begin{array}{c}\text { Existing } \\
\text { Capability Y }\end{array}$ & $\begin{array}{c}\text { Existing } \\
\text { Capability Z }\end{array}$ & $\begin{array}{c}\text { Ideal } \\
\text { level }\end{array}$ \\
\hline Technical devices & 0,709 & 0,947 & 0,960 & 1,000 \\
\hline Human Resources (soldier) & 0,764 & 0,979 & 0,979 & 1,000 \\
\hline Information devices & 0,923 & 0,947 & 0,950 & 1,000 \\
\hline Organization devices & 0,764 & 0,900 & 0,907 & 1,000 \\
\hline
\end{tabular}

Furthermore, the results of the compilation of the assessment of the four components, illustrated in graphical form, which illustrates the overall comparative technological capabilities of the warships, as well as the results of the assessment for each warship.

Based on Figure 1, at the level of technological capability and the existing gap of fourth components, where the current level of capability on warships $W$ has a gap of the technological development that is farthest away with countries $Y$ and $Z$ is the development of the level of technological capability on technical devices and followed by developments the level of technological capability in human resources (soldiers). In the aspect of technical equipment, the development of technological capabilities of warships in $\mathrm{W}$ countries is indeed still constrained by the weak data processing and technology. But it can be overcome with the support of government policies that apply technology transfer agreements for the transfer of know-how in every warship order, so that they can produce to design warships independently. Where is a very strategic opportunity at this time, many have been licensed and supported by superior research and innovation from within the country.

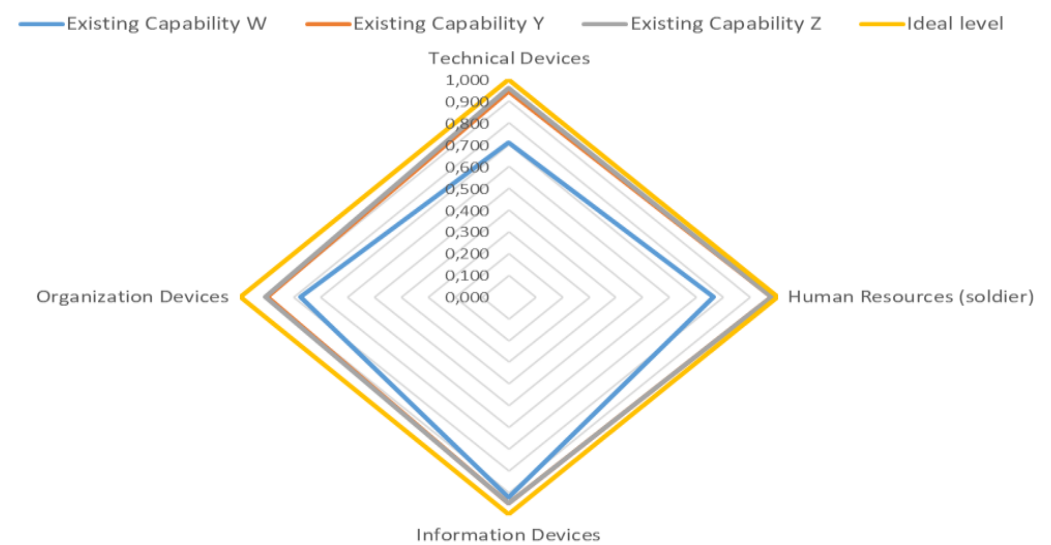

Fig 1. Comparative overall technological capabilities and existing gap of fourth components. 
In the aspect of human resources, especially war ship soldiers. As a maritime country, HR personnel must be qualified and professional in catching up. Increased education and training in supporting technology transfer cooperation until the transfer of know how is expected to run in a balanced manner and continue to HR can become the main capital in supporting the production of warships independence, includes information and support tools.

\section{CONCLUSION}

The level of technological capability of warships in $W$ countries is below the warship technology capabilities in countries $Y$ and $Z$, this is because they have significant abilities in carrying out projects independently and have a strategic view in the aspects of development and development of technological capabilities in the aspects of technical equipment and human resources. Because of the capability-based planning approach of each country, they have the ability to formulate strategies in increasing internal and external competence in the technical, managerial domain, managing human resources, management information and also managerial organizations.

This capability assessment technology model provides an appropriate framework for assessing technological capabilities on warships. A holistic view of evaluating technological capabilities in a technical device, human resources, information devices and organizational devices is very important, both qualitative and quantitative. Graphically, this model can visualize every dimension of technological capability, so that an assessment can be made regarding the strengths and weaknesses of the ability currently faced with ideal conditions. So the technology capability assessment model has proven to be one of the approaches in analysing and comparing the competitiveness of technological capabilities on warships, identifying weaknesses of warships and can be used as a consideration in determining the right strategy to improve and develop it.

The assessment of technological capabilities related to warships also faces limitations, due to the lack of information and data specifically obtained as a result of confidentiality concerning the conditions available on warships. Future research is expected to find more specific and suitable criteria for assessing technological capabilities and assessing dynamic capabilities in military equipment, both in the army, navy and air force.

\section{REFERENCES}

Alkadri, Dodi, S., Muchdie, Siswanto, S., \& Fathoni, M. (2001). Technology Management for Regional Development: Basic Concepts, Case Examples, and Policy Implications. Jakarta: Directorate of Technology Policy for Regional Development, BPPT.
Brown, E. (2004). Evaluation and prediction of technology in Boshehri. Tehran: A \& Malekifar, A (Trans.).

Ciptomulyono, U. S., \& Handayani. (2003). Implementation of ANP Approaches in Techometric Methods for Technology Content Analysis (Case Study: PT.Platinum Ceramics Industri). Surabaya: Sepuluh November Institute of Technology.

Correia, J. (2019). Military Capabilities and the Strategic Planning Conundrum. Security and Defence Quarterly, 24(2). doi:https://doi.org/10.35467/sdq/108667

ESCAP, E. a. (1988e). Technology Capability Assesment. Bengalore: APCTT.

James, D. A. (2013). Emerging Technologies and Military capability. Singapore: S. Rajaratnam School of International Studies, Nanyang Technological University .

Jerusalem, M. (2002). Atlas Project Method Technology and School-Based Quality Improvement Management as Educational Service Quality Assurance Tools. Yogyakarta: Faculty of Engineering Yogyakarta State University.

Jiang, W. (2001). Technological Capability Assessment as a Strategic Tool: Cases in Chinese Manufacturing Firms. Portland International Conference on Management of engineering and Technology. 1. Portland, USA: hysica E-low-dimensional Systems \& Nanostructures - PHYSICA E. doi:10.1109/PICMET.2001.952130

Kenny, S., \& et.al. (2015). Global Marine Technology Trends 2030 . Southampton : Lloyd's Register Global Technology Centre Southampton Boldrewood Innovation Campus Burgess Road.

Khamseha, A., Habibitabarb, Z., \& Shadkamc, A. S. (2014). Assessment and Analysis of Technological Capabilities in Iranian Oil \& Gas Industries (Case study: Oil And Energy Industries Development Company of Qeshm) . Indian Journal of Scientific Research, 504513.

Kusumaningtyas, D. (2010). Implementation of Technology Assessment in Air Traffic Control at Juanda Airport Using Technometric Approach. Surabaya: Sepuluh November Institute of Technology.

MiRVAKILI, A. A. (2015). The Assessment of Technological Capabilities of Wagon and Locomotive Manufacturing Industries of Urban Trains (Case Study: Tehran Wagon). 
Cumhuriyet University Faculty of Science Science Journal (CSJ), 36, 2799-2806.

Mohammadi, M., Elyasi, M., \& Kiasari, M. M. (2014). Developing a Model for Technological Capability Assesment (case of Automotive Parts Manufactures in Iran). International Journal of Innovation and Technology Management, 1450014 (1-19).

Phaal, R., Farrukh, C., \& Probert, D. (2004). A framework for supporting the management of technological knowledge. International Journal of Technology Management, 1-15.

Phaal, R., Farrukh, C., \& Probert, D. R. (2001). Technology management process assessment: A case study. International Journal of Operations and Production Management, 1116-1132.

Putra, I. N., Hakim, A., Pramono, S. H., \& Tolle, H. (2017). Adopted COBIT-5 Framework for System Design of Indonesia Navy IS/IT : An
Evaluation. International Journal of Applied Engineering Research, 6420-6427.

Ramadhani, Y. (2012). Analysis of Company Competitiveness in terms of Technology Assessment. TECHNOSCIENTIA Technology Journal, 109-115.

Sadler, R. (2015). Foreword on Global Marine Technology Trends 2030. Southampton: Lloyd's Register Global Technology Centre Southampton Boldrewood Innovation Campus Burgess Road.

Sharif, M. N. (1988). Basis for Techno-economic Policy Analysis. Science and Public Policy, 15(4).

Technology Atlas Project Team. (1987). Components of Technology for Resources Transformation. Technological Forecasting and Social Change, 32, 19-36. 